\title{
Pigments Characterization and Molecular Identification of Bacterial Symbionts of Brown Algae Padina sp. Collected from Karimunjawa Island
}

\author{
Damar Bayu Murti¹, Abe Susanto², Ocky Karna Radjasa², Ferdy Semuel Rondonuwu ${ }^{1 *}$ \\ ${ }^{1}$ Graduate School of Biology - Satya Wacana Christian University \\ Jl. Diponegoro No. 52-60 Salatiga Indonesia 50711 \\ ${ }^{2}$ Faculty of Fisheries and Marine Science - Diponegoro University \\ Jl. Prof. H. Soedharto, SH, Tembalang Semarang 50275 \\ Email : ferdy@staff.uksw.edu
}

\begin{abstract}
The search for carotenoids in nature has been extensively studied because of their applications in foods. One treasure of the biopigment source is symbiotic-microorganisms with marine biota. The advantages of symbiont bacteria are easy to culture and sensitize pigments. The use of symbiont bacteria helps to conserve fish, coral reefs, seagrass, and seaweed. Therefore, the bacteria keeps their existence in their ecosystems. In this study, bacterial symbionts were successfully isolated from brown algae Padina sp. The bacterial symbionts had yellow pigment associated with carotenoids. The pigments were characterized using High Performance Liquid Chromatography (HPLC) with a Photo Diode Array (PDA) detector. The carotenoid pigments in the bacterial symbionts were identified as dinoxanthin, lutein and neoxanthin. Molecular identification by using a 165 rRNA gene sequence method, reveals that the bacterial symbionts were closely related to Bacillus marisflavi with a homology of $99 \%$.
\end{abstract}

Keywords : carotenoid pigments, brown algae, Padina, bacterial symbionts, $16 \mathrm{~S}$ rRNA

\section{Introduction}

Pigments are one of the fundamental molecules in photosynthetic organisms. Photosynthetic organisms, including bacteria and fungi, produce phycobilins (phycocyanin, phycoerythrin), chlorophylls (chlorophyll-a, chlorophyll- $b$, chlorophyll-c), and carotenoids, ( $\beta$ carotene, lutein, fucoxanthin, anthocyanin) (Kong et al., 2010). Carotenoids are well known as an antioxidant and pro-vitamin A to protect the retina from macular degeneration (Steven et al., 2000; Mares et al., 2002; Sashidaran et al., 2013). Carotenoids enhance the immune response and inhibit many types of cancers (Guerin et al., 2003). Carotenoids also help to treat vitamin A deficiency through dietary intake and cancer due to their highantioxidant activity.

Carotenoids are one class of 800 natural fatsoluble pigments found in plants, algae, and photosynthetic bacteria. Carotenoids can be obtained from many natural sources such as leaves, fruits, coral reefs, seaweed, and fish in terrestrial or marine environments (Sommer et al., 1996; Ross, 1999; Olson, 1999). Carotenoids have two main functions in photosynthetic organisms in photoprotection and light-harvesting (Ackleson, 2003; Du et al., 2006).
A relatively large amount of heterotrophic bacteria that synthesize carotenoids have been isolated from coastal and oceanic waters (Du et al., 2006). However, the widespread occurrence of carotenoids in non-phototrophic bacteria suggests that their presence is crucial for the viability of these organisms in their natural environments (Satfsnes et al., 2010). Streptomyces, Pseudomonas, and Vibrio are among marine bacteria that produce the bioactive compounds (Jafarzade et al., 2013). Marine bacteria can be an alternative source for exploring marine natural products with promising bioactive compounds. In this preliminary research, the characterization of carotenoid pigments and identification of bacterial symbionts with brown algae Padina sp. collected from Karimunjawa Island is reported.

\section{Materials and Methods}

Sampling, collection of samples, and bacterial isolation

Colonies of brown algae Padina sp. were collected from Menjangan Kecil waters, Karimunjawa islands, Jepara, and North Java Sea, Indonesia by scuba diving. Upon collection colonies 
were put into sterile plastic bags (Whirl-Pak, Nasco, USA). The tissues were then rinsed with sterile seawater and homogenized with mortar. The homogenized tissues were serially diluted, spread on $1 / 2$ strength ZoBell 2216E, and incubated at room temperature for 48 hours. On the basis of morphological features, 10 colonies were randomly picked and purified by making streak plates (Madigan et al., 2000).

\section{Pigment extraction}

Twenty plates of bacterial symbionts of Padina sp. cultured on Zobell agar medium were collected. A total of 1 gram of pellets were extracted using cold $100 \%$ acetone (Pro Analyst) (Wusqy et al., 2014), with the aid of a sonicator (Britton et al., 1995). The extracted pigments were filtered using filter paper Whatman no. 1. Afterwards, the pigments were then dried by the use of nitrogen $\left(\mathrm{N}_{2}\right)$ gas flow.

\section{Identification and analysis of pigment content}

Pigments were identified and analyzed by using High Performance Liquid Chromatography (HPLC) Shimadzu LC-20 in reverse phase column AB with ODS, C18, having a diameter of $4 \mathrm{~mm} \times 25 \mathrm{~mm}$ (Nugraheni et al., 2010). The mobile phase was comprised of a mixed methanol-acetone solution. The samples were monitored at a wavelength of $190-800 \mathrm{~nm}$ with a flow rate of $1 \mathrm{ml} / \mathrm{min}$ and a pressure of 1000 psi.

\section{DNA Extraction of bacterial symbiont}

The genomic DNA of bacterial symbiont was extracted by using Chelex 100. Bacterial symbiont pellet cells were added with $100 \mu \mathrm{l}$ of $\mathrm{ddH}_{2} \mathrm{O}$. The mixture was then added with $1 \mathrm{ml}$ of $0.5 \%$ saponin in Phosphate-buffered saline (PBS) 1X, allowed for an overnight temperature of $4^{\circ} \mathrm{C}$. The mixture was centrifuged at 12000 RPM for 10 minutes then $1 \mathrm{ml}$ of PBS $1 X$ was added and centrifuged again at 12000 RPM for $5 \mathrm{~min}$. The mixture was added to $100 \mu \mathrm{l}$ of $\mathrm{dd}_{2} \mathrm{O}$ and $50 \mu \mathrm{l}$ of $20 \%$ chelex 100 . After that, the mixture was boiled for $10 \mathrm{~min}$ in hot water with temperature of $95^{\circ} \mathrm{C}$, and vortexed once after 5 min. Subsequently, the mixture was run at 12000 RPM for $10 \mathrm{~min}$. The genomic DNA was transferred to a clean Eppendorf tube. The DNA extraction was stored at $-20^{\circ} \mathrm{C}$.

\section{S rRNA Polymerase Chain Reaction}

Determining the temperature cycle in running PCR followed the following pattern: $94^{\circ} \mathrm{C}$ for 2 minutes to initial denaturation, $94^{\circ} \mathrm{C}$ for $1 \mathrm{~min}$ to denaturation, $55^{\circ} \mathrm{C}$ for $1 \mathrm{~min}$ to annealing, and $72^{\circ} \mathrm{C}$ for $2 \mathrm{~min}$ to extension respectively. The cycles were repeated for denaturation, annealing and extension until 45 cycles (Murti and Radjasa, 2012). To amplify the 16S rRNA gene, Eubacteria universal primers 27F (5'-AGAGTTTGATCMTGGCTCAG-3'), and primer 1492R (5'- TACGGYTACCTTGTTACGACTT-3') were used (Long and Azam, 2001). PCR product visualization was done by using electrophoresis on $2 \%$ agarose. The DNA sequencing analysis was done according to Murti and Radjasa (2012).

\section{Results and Discussion}

One isolate was selected, namely MKPD3, which was found to produce a yellow pigment and was expected to sensitize one kind of carotenoid.The absorption spectrum of bacterial symbiont was detected from 350-800 $\mathrm{nm}$ by using a spectrophotometer UV-Vis (Fig. 2). There were three peaks detected in bacterial symbiont (Fig. 3). As a result, the characterization of carotenoids in bacterial symbiont were dinoxanthin, lutein and neoxanthin (Table 1).

PCR amplification of bacterial symbiont using 16S rRNA showed positive results with the presence of DNA bacterial symbiont with an appropriate base length of approximately $1500 \mathrm{bp}$ (Fig. 4). The phylogenetic tree shown in Fig. 5 was closely related to other microorganisms. By using molecular identification with a two-direction sequencing of the PCR product, it was found that the bacterial symbiont was very close to Bacillus marisflavi with 99\% similarity (Table 2 ).

Brown algae are generally known as trash seaweed on shorelines. On the other hand, brown algae have many natural compounds which are useful in many pharmaceutical and food studies. In this study, Padina sp. was used as a sample because of its potential in natural bioactive compounds like antioxidants (Setha et al., 2013), antibacterial compounds (Al-Zahrani et al., 2014), and antifungal compounds (Nogueira et al., 2014). Commonly, Padina sp. grow abundantly in tropical regions on reef flats and outer reef slopes

Table 1. List of characterization of carotenoid pigments in MKPD3 (Jeffrey et al., 1997; Roy et al., 2011)

\begin{tabular}{cccc}
\hline No & $\begin{array}{c}\text { Retention time } \\
(\mathrm{min})\end{array}$ & Abs. Peak & $\begin{array}{c}\text { Pigment } \\
\text { name }\end{array}$ \\
\hline 1 & $7.15^{\prime}$ & $425,449,474$ & Dinoxanthin \\
2 & $9.72^{\prime}$ & $416,447,472$ & Lutein \\
3 & $26.52^{\prime}$ & $417,438,467$ & Neoxanthin \\
\hline
\end{tabular}


Table 2. Molecular identification of bacterial symbiont

\begin{tabular}{lcccc}
\hline Isolate & $\begin{array}{c}\text { Length } \\
(\mathrm{bp})\end{array}$ & $\begin{array}{c}\text { Closest } \\
\text { Relative }\end{array}$ & $\begin{array}{c}\text { Homology } \\
(\%)\end{array}$ & $\begin{array}{c}\text { Accession } \\
\text { no. }\end{array}$ \\
\hline MKPD3 & 918 & $\begin{array}{c}\text { Bacillus } \\
\text { marisflavi }\end{array}$ & 99 & KJ011883.1 \\
\hline
\end{tabular}

(N'Yeurt and Payri, 2006; Sillberfeld et al., 2013). Morphologically, these algae have a typical fanshaped thallus, so that it makes the genus Padina easily recognizable in the field (Sillberfeld et al., 2013).

Marine algae are classified as green algae (chlorophyta), brown algae (phaeophyta) and red algae (rodophyta) on the basis of chemical composition. It was determined by the color presence of chlorophyll- $a$ and $-b, \beta$-carotene (a yellow pigment) and various characteristic xanthophylls (yellowish or brownish pigments) (Chinnadurai et al., 2013). The primary xanthophyll pigment in brown algae is fucoxanthin. Nevertheless, there are other xanthophylls in the phaeophyceae class like diatoxanthin, diadinoxanthin, violaxanthin, flavoxanthin, lutein, neoxanthin, tareoxanthin, and violeoxanthin (Strain et al., 1944). From the HPLC data, it was evident that bacterial symbionts produced three xanthophyll pigments consisting of dinoxanthin, lutein and neoxanthin. It was confirmed by Strain et al. (1944) that brown algae possess other xanthophyll pigments beside fucoxanthin.

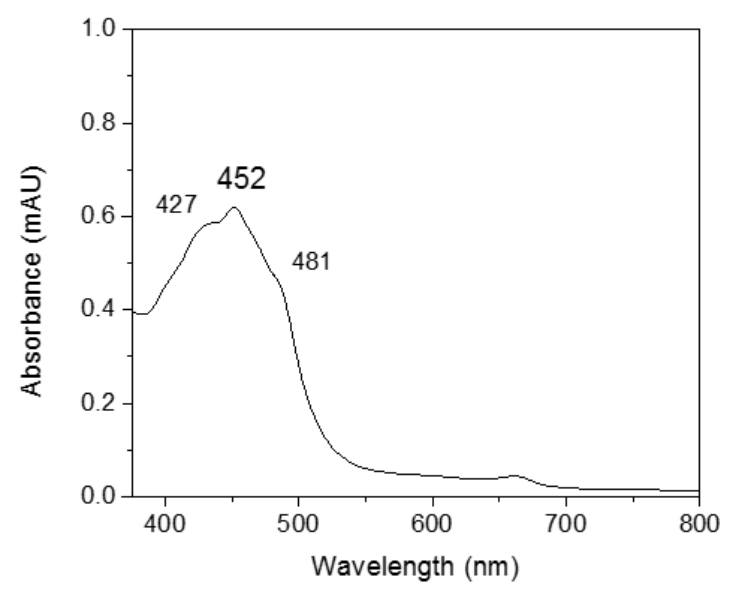

Figure 1. UV-Vis absorption spectrum of MKPD3 crude extracts

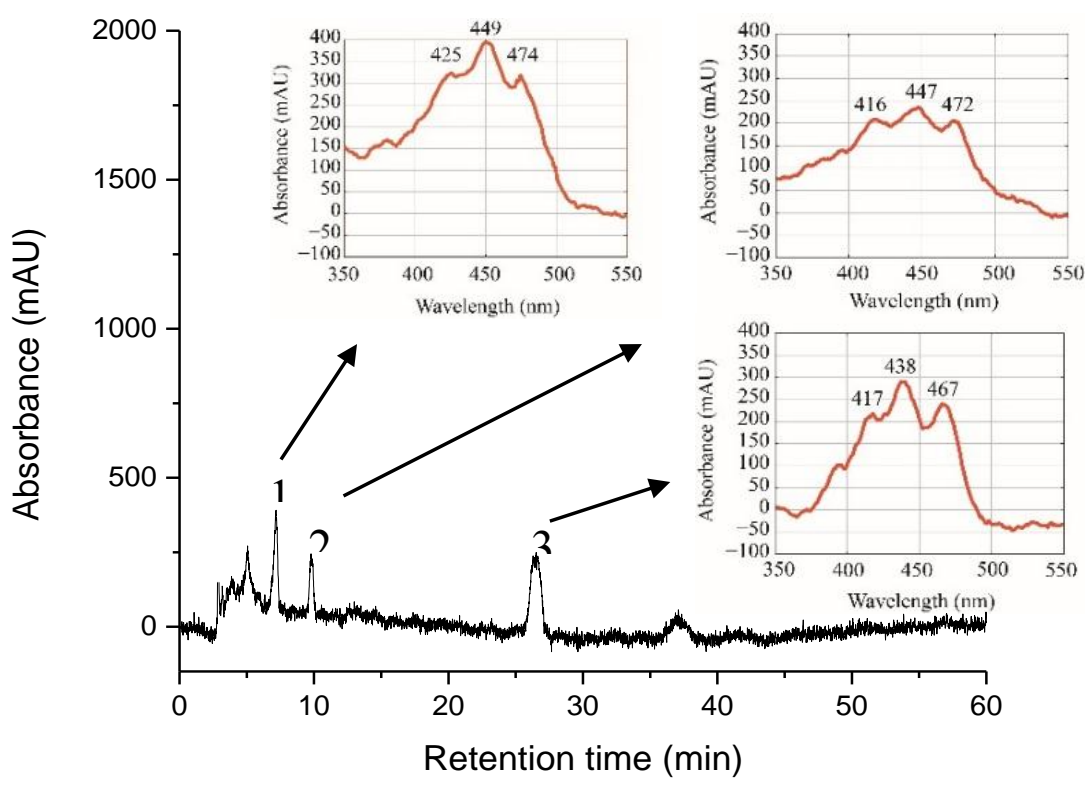

Figure 2. The characterization of carotenoid pigments of MKPD3 analyzed by using HPLC 


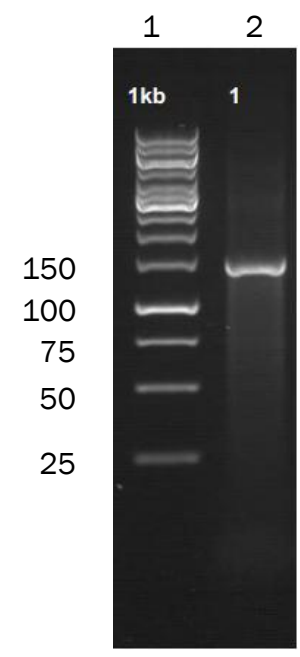

Figure 3. PCR amplification of 16S rRNA fragments. 1: Marker, 2: MKPD3

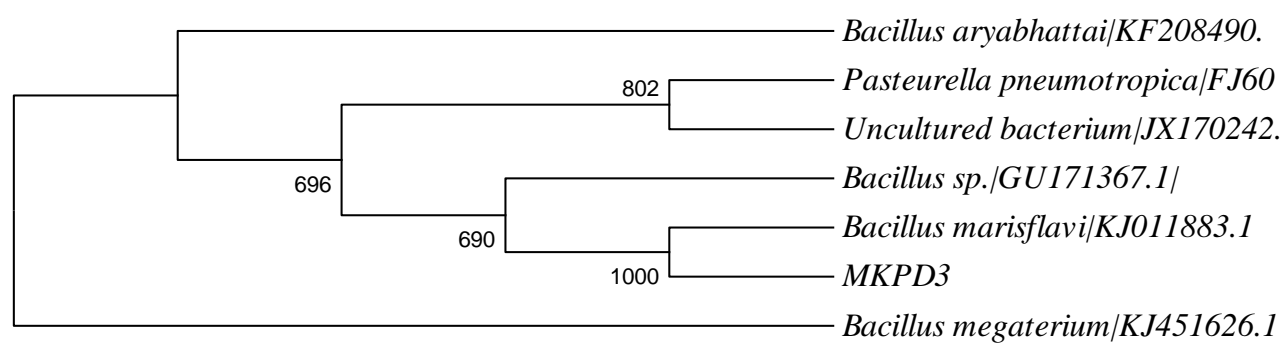

Figure 4. Phylogenetic tree based on $16 \mathrm{~S}$ rRNA gene sequences of strain MKPD3

Therefore, it is true that symbiont bacteria synthesize similar bioactive compounds like the host.

Several studies on bacterial symbionts have shown that they have potential to function as natural pigment sources and bioactive compounds. Radjasa et al. (2008) reported that a marine bacterium Pseudoalteromonas piscicida $\mathrm{H} 1.7$ isolated from Kakaban Land-Locked Marine Lake showed antibacterial activity towards Staphyllococcus aureus and produced a yellow pigment. Another report from Khoeri et al. (2011) mentioned that bacterial symbionts of Tunicate Didemnum molle with Virgibacillus sp. showed antibacterial potential towards MDR bacteria and amplified Non-Ribosomal Peptide Synthetase (NRPS) gene fragments. In addition, Murti and Radjasa (2012) reported that the marine bacterium Paenibacillus campinasensis isolated from soft coral Lobophytum sp. also showed antibacterial activity towards E.coli and S.aureus.

Recently, Khaneja et al. (2009) successfully identified bacteria from soil, sea water and the human gastrointestinal tract that produced carotenoid pigments. They mentioned that Bacillus marisflavi was isolated from soil produced carotenoids. The first report of Bacillus marisflavi was proposed by Yoon et al. (2003). Gram-positive, endospore-forming, and moderately halophilic rods are the characteristics of this bacteria group. Moreover, B. marisflavi has ellipsoidal endospores observed at a subterminal or central position in swollen sporangia and isolated from sea-water of a tidal flat of the Yellow Sea in the Korean Peninsula.

Colonies are pale yellow, smooth, convex, circular to slightly irregular, slightly raised, and 2-4 $\mathrm{mm}$ in diameter after 3 days of growth at $30^{\circ} \mathrm{C}$ on MA. The growth temperature is optimally at $30-37^{\circ} \mathrm{C}$. Usually, it grows at $10^{\circ} \mathrm{C}$ and $44^{\circ} \mathrm{C}$, but not at $4^{\circ} \mathrm{C}$ or above $48^{\circ} \mathrm{C}$. The optimum $\mathrm{pH}$ for these bacteria is at 6.0-8.0; occurs at a pH of 4.5 and 9.0. In contrast, B. marisflavi do not grow at a pH of 4.0 (Yoon et al., 2003). Most species of this genus have carotenoids associated with either the vegetative cell or the spore (Moeller et al., 2005; Duc et al., 2006).

\section{Conclusion}

The bacterial symbionts of Padina sp. have potency as a carotenoids source. Strain MKPD3 contained three essential pigments consisting of 
dinoxanthin, lutein, and neoxanthin as shown by HPLC analysis. The bacterial symbionts Bacillus marisflavi capable of synthetizing similar pigments to its host organisms. Nevertheless, more developmental research is needed on the applications of carotenoids and bacterial symbionts.

\section{Acknowledgment}

Authors give gratitude to Ferry Karwur, Ph.D. for providing instruments that all we need in Graduate School of Biology, Satya Wacana Christian University (SWCU), Salatiga. We also give thanks to Ministry of Education and Culture through "Biro Perencanaan Kerjasama Luar Negeri" through "Beasiswa Unggulan" for supporting this study. My gratitude is addressed to Mr. Andrew Thren for some advises in this paper.

\section{References}

Ackleson, S.G. 2003. Light in shallow waters: a brief research review. Limmol. Oceanogr. 48: 323328.

Al-Zahrani, A., Al-Haj, N., Omer, H. \& Al-Judaibi, A. 2014. Impact of Extracts of Marine Macroalgae on Multidrug-Resistant Bacteria. J. Microbiol. Res. 4(6A):18-24. doi: 10.5923/s.microbiology.20 1401.03.

Britton, G., Liaaen-Jensen, S. \& Pfander, H. 1995. Carotenoid Birkläuser Verlag Basel. Boston. Berin. doi: 10.1016/S0940-2993(97)80097-8

Chinnadurai, S. 2013. Estimation of major pigment content in seaweeds collected from Pondicherry coast. Int. J. Sci. Tech. 9(1): 522525. ISSN-2319-2119.

Duc, L.H., Fraser, P. \& Cutting, S.M. 2006. Carotenoids present in haloterant Bacillus spore formers. FEMS. Microbiol. Lett. 255: 215-224. doi: 10.1111/j.15746968.2005.00091.x.

Du, H., Jiao, N., Hu, Y. \& Zeng, Y.. 2006. Diversity and distribution of pigmented heterotrophic bacteria in marine enviroinments. FEMS Microbiol. Ecol. 57:92-105. doi: 10.1111/j.1574-6941.2006. 00090.x

Guerin, M., Mark, E.H., \& Olaizola, M. 2003. Haematococcus Astaxanthin: Applications for human health and nutrition. Trends in Biotechnol. 21: 210-216. doi: 10.3390/md903 0319
Jafarzade, M., Yahya, N.A., Mohamad, S., Usup, G. \& Ahmad, A., 2013. Isolation and characterization of pigmented bacteria showing antimicrobial activity from Malaysian marine environment. Mal. J. Microbiol. 9(2): 152-160. ISSN (print): 1823-8262, ISSN (online): 22317538.

Jeffrey, S.W., Mantoura, R.F.C., \& Wright, S.W. 1997. Phytoplankton pigments in oceanography: guidelines to modern methods. UNESCO publishing: Paris. ISBN: 92-3-103275-5. doi: 10. 1023/A:1007168802525.

Khaneja, R., Perez-Fons, L., Fakhry, S., Baccigalupi, L., Steiger, S., To, E., Sandmann, G., Dong, T.C., Ricca, E., Fraser, P.D., \& Cutting, S.M. 2009. J. Appl. Microbiol. 108: 1889-1902. doi: 10.1111 /j.1365-2672.2009.04590.x.

Khoeri, M.M., Radjasa, O.K., Sabdono, A., \& Sudoyo. 2011. H. Bioprospecting of Bacterial Symbiont of Tunicate Didemnum molle From Sambangan, Karimunjawa Islands. J. Coast. Dev. 14(3): 255261.

Kong, K.W., Khoo, H.E., Prasad, K.N., Ismail, A., Tan, C.P. \& Rajab, N.F. 2010. Revealing the Power of the Natural Red Pigment Lycopene. Mol. 15: 959-987. doi: 10.3390/molecules15020959.

Long, R.A. \& Azam, F. 2001. Antagonistic Interactions among Marine Pelagic Bacteria. Appl Environ. Microbiol. 67(11): 4975-4983. doi: 10.1128/AEM.67.11.4975-4983.2001.

Madigan, M.T., Martinko, J.M. \& Parker, J. 2000. Brock Biology of Microorganism. Prentice Hall. New Jersey. doi: 10.1016/S0301-9268(99)00 013-3.

Mares-Perlman, J.A., Millen, A.E., Ficek, T.L. \& Hankinson, S.E. 2002. The body of evidence to support a protective role for lutein and zeaxanthin in delaying chronic disease. Overview. J. Nutr. 132: 5185-5245.

Moeller, R., Horneck, G., Facius, R., \& Stackebrandt, E. 2005. Role of pigmentation in protecting Bacillus sp. endospores against environmental UV radiation. FEMS. Microbiol. Ecol. 51: 231236. doi: 10.1016/j.femsec.20 04.08.008.

Murti, P.D.B. \& Radjasa, O.K. 2012. Antibacterial Activity of Bacterial Symbiont of Soft Coral Lobophytum sp. Against MDR Bacteria Escherichia coli and Staphyllococcus aureus. J. Coast. Dev. 15(3):297-302. 
Nogueira, L.F.B., Morais, E.C., Brito, M.A.D., Santos, B.S., Vale, D.I., Lucena, B.F.F., Figueredo, F.G., Guedes, G.M.M., Tintino, S.R., Souza, C.E.S., Nogueira, R.B.S.S., Matias, E.F.F., MoraisBraga, M.F.B., Cunha, E.V.I., Lima, M.A. \& Coutinho, H.D.M. 2014. Evaluation of Antibacterial, Antifungal and Modulatory Activity of Methanol and Ethanol Extracts of Padina sanctae-crucis. African Health Sci. 14(2): 372376.

Nugraheni, S.A., Khoeri, M.M., Kusmita, L., Widyastuti, Y. \& Radjasa, O.K. 2010. Characterization of Carotenoid Pigments from Bacterial Symbionts of Seagrass Thalassia hemprichii. J. Coast. Dev. 14(1): 51-60.

N'Yeurt, A.D.R. \& Payri, C.E. 2006. Marine algal flora of French Polynesia I. Phaeophyceae (Ochrophyta, brown algae). Crypt. Algol. 27:111-152

Olson, J.A. 1999. Modern nutrition in health and disease. Baltimore: Williams \& Wilkins. $9^{\text {th }}$ ed. 525-541.

Radjasa, O.K., Limantara, L. \& Sabdono, A. 2008. Antibacterial Activity of a Pigment ProducingBacterium Associated With Halimeda sp. From Land-Locked Marine Lake Kakaban, Indonesia. J. Coast. Dev. 12(2): 100-104.

Roy, S., Llewellyn, C.A., Egeland, E.S. \& Johnsen, G. 2011. Phytoplankton Pigments: Chracterization, Chemotaxonomy and Applications in Oceanography. UK, Cambridge Univ. Press. ISBN: 978-1-107-00066-7 Hardback.

Ross, A.C. 1999. Modern nutrition in health and disease. Baltimore: Williams \& Wilkins. $9^{\text {th }}$ ed. 305-327.

Sasidharan, P., Raja, R., Karthik, C. Ranandkumar, S. \& Indra, A.P. 2013. Isolation and characterization of yellow pigment producing Exiguobacterium sps. J. Biochem. Tech. 4(4): 632-635. ISSN: 0974-2328.
Satfsnes, M.H., Josefsen, K.D., Andersen, G.K., Valla, S., Ellingsen, T.E. \& Bruheim, P. 2010. Isolation and Characterization of Marine Pigmented Bacteria from Norwegian Coastal Waters and Screening for Carotenoids with UVA-Blue Light Absorbing Properties. The J. Microbiol. 48(1): 16-23. doi: 10.1007/s12275-009-0118-6.

Setha, B., Gaspersz, F.F., Idris, A.P.S., Rahman, S., \& Mailoa, M.N. 2013. Potential of Seaweed Padina sp. As A Source of Antioxidant. Int. J. Sci. Tech. Res. 2(6): 221-221.

Sillberfeld, T., Bittner, L., Garcia, C.F., Cruaud, C., Rousseau, F., Reviers, B., Leliaert, F., Payri, C.E., \& Clerck, O.D. 2013. Species Diversity, Phylogeny and Large Scale Biogegraphic Patterns of The Genus Padina (Phaeophyceae, Dictyotales). J. Phycol. 49: 130-142.

Sommer, A. West \& K.P. Jr. 1996. Vitamin A deficiency: health, survival, and vision. Oxford: Oxford Univ. Press.

Steven, M., Calara, B. \& Ayako, Y. 2000. $\beta$-carotene and selenium supplementation enhances immune response in aged human. Int. Grat. Med. 2(2/3): 85-92.

Strain, H.H., Manning, W.M. \& Hardin, G. 1944. Xanthophylls and carotenes of diatoms, brown algae, dinoflagellates, and sea anemones. Biol. Bull. 86(3): 169-191.

Wusqy, N.K., Limantara, L. \& Karwur, F.F. 2014. Exploration, Isolation and Quantification of $\beta$ carotene from Bacterial Symbiont of Acropora sp. Microbiol. Indones. 8(2): 58-64. doi: 10.54 54/mi.8.2.3

Yoon, J.H., Kim, I.G., Kang, K.H., Oh, T.K. \& Park, Y.H. 2003. Bacillus marisflavi sp. nov. and Bacillus aquimaris sp. nov., isolated from sea water of a tidal flat of the Yellow Sea in Korea. Int. J. Sys. Evo. Microbiol. 53: 1297-1303. doi: 10.1099 /ijs.0.02365-0. 